\title{
Patent Trolls on Markets for Technology - An Empirical Analysis of Trolls' Patent Acquisitions
}

September 2009

\author{
Timo Fischer ${ }^{1}$, Joachim Henkel ${ }^{1,2}$
}

\footnotetext{
${ }^{1}$ Schöller Chair in Technology and Innovation Management, Technische Universität München Arcisstr. 21, D-80333 Munich, Germany. +49-89-289-25760; fischer | henkel @wi.tum.de

${ }^{2}$ Center for Economic Policy Research (CEPR), London
}

Patent trolls-firms that appropriate profits from innovation by enforcing patents against infringers - are peculiar players on markets for technologies. As buyers of patents, they are solely interested in the exclusion right, not in the underlying knowledge. Similarly, when they sell or license out patents, the transaction does not involve a technology transfer. In this paper, we empirically analyze trolls' patent acquisitions. We draw on a unique dataset of 753 patents acquired by known patent trolls, which we compare to 1506 patents acquired by practicing firms. Our findings regarding patent characteristics support recent theoretical propositions about the troll business model. Trolls focus on patents that have a broad scope and that lie in patent thickets. Furthermore, and contrary to common belief, we find that troll patents are of significantly higher quality than those in the control group, a result that suggests sustainability of the troll business in the future. Extrapolating from our findings, we posit that transactions involving patent trolls may only be the tip of the iceberg of "patent-only" transactions, a conjecture with strong implications for the efficiency of markets for technologies. Managerial and policy implications are discussed.

Keywords: markets for technology, patent acquisitions, patent trolls, empirical study JEL classification: M10, O34 


\section{Introduction}

Patent trolls, or nonpracticing entities (NPEs), are firms whose business model is focused on enforcing patents against infringers and thus to receive damages or settlement payments (e.g., Reitzig et al., 2007). Patent trolls are considered by some as a serious threat to innovation in high-tech industries, and have received considerable attention from policy makers (e.g., U.S. Federal Trade Commission, 2003; Jaffe and Lerner, 2004; Lemley and Shapiro, 2007). Extant research has studied the legal underpinnings of the troll business (Magliocca, 2006; Golden, 2007; Lemley and Shapiro, 2007), provided (some) empirical evidence on troll-type patent litigation (Lerner, 2006; Magliocca, 2006; Reitzig et al., 2009), and illuminated the various strategies underlying the troll business and its sustainability to policy changes (Reitzig et al. 2007; Henkel and Reitzig, 2009).

However, a systematic quantitative study of patent troll activity is lacking, and with it an empirically based judgment about the strategies, technology fields, and sustainability of future troll activity. Such judgment is critical, though, both for policy makers aiming at curtailing the troll business and for managers facing the threat of patent troll attacks.

The current lack of empirical studies is mainly due to data availability issues. Many infringement cases involving trolls are settled out of court, and even those that do end up in court are difficult to gather. We thus pursue a different route, by analyzing trolls' patent acquisitions. In so doing, we obtain a systematic and rather complete outlook on those patent troll activities that are based on acquired patents, which constitute a considerable and growing share (Reitzig et al., 2009, Table 1 and Figure 2).

We draw on a unique dataset of 753 patents acquired by known patent trolls, which we compare to 1506 patents acquired by practicing firms. Our findings regarding patent characteristics support our hypotheses, derived from the literature and from considerations of the troll business model. Trolls seem to be able to acquire patents that are most appropriate for their business model. Compared to practicing firms, trolls focus on patents that (a) have a broad scope and are thus infringed upon with a high probability, and (b) lie in patent thickets and thus have a high substitution cost. Most importantly, and contrary to common belief, we find that (c) troll patents on average are of significantly higher quality than those in the control group and thus have a high probability of being upheld in court. The latter result in particular suggests sustainability of the troll business in the future. 
Beyond the analysis of trolls' patent acquisitions, our study contributes to the understanding of markets for technology (e.g., Arora and Gambardella, 1994; Gans and Stern, 2003; Lamoreaux and Sokoloff, 1999; Arora et al., 2001) more generally. Trolls often procure their patents by acquisition (as laid out above) or by in-licensing (Reitzig et al., 2009, Table 1). On the selling side, they always generate their revenues as licensors or sellers of patents. Hence, patent trolls appear to be very active players on markets for technology, as both buyers and sellers. But trolls are rather peculiar participants in these markets. As Reitzig et al. (2009) point out with a focus on trolls' role as sellers, the troll phenomenon calls into question the established notion that intellectual property rights improve the functioning of markets for technology. However, we argue that trolls challenge our understanding of markets for technology more fundamentally. As buyers of patents, they are solely interested in the exclusion right, not in the underlying knowledge. Similarly, when trolls sell or license out patents, the transaction again does not involve a technology transfer, since by definition of the troll business model the potential licensee already uses the patented invention. Extrapolating from our empirical analysis, we posit that transactions involving patent trolls may only be the tip of the iceberg of "patentonly" transactions. Patent transactions may thus be, to a good extent, indications not of efficiency-enhancing knowledge trading and division of labor, but rather of-inefficientduplication of inventions and failure of ex-ante licensing.

The remainder of the paper is structured as follows. In Section 2, we discuss the troll business model, review the pertaining literature, and derive hypotheses. In Section 3 we describe our data and empirical strategy. In Section 4 we present our results. Section 5 concludes.

\section{Background and Hypotheses}

\subsection{The Patent Troll Business Model}

We follow Reitzig et al. (2007, p. 137) in defining "patent sharks or trolls as individuals or firms that seek to generate profits mainly or exclusively from licensing or selling their (often simplistic) patented technology to a manufacturing firm that, at the point in time when fees are claimed, already infringes on the shark's patent and is therefore under particular pressure to reach an agreement with the shark.” The term "nonproducing entity" or "nonpracticing entity" is often used synonymously to "patent troll" and "patent shark" and has the advantage of avoiding a derogatory connotation. However, it equally describes pure research firms and institutions that seek to license their technologies ex ante, i.e., before infringement occurred. To avoid this 
misunderstanding, we use the common term "patent troll” in this paper. In doing so, we do not imply a moral judgment. A firm fitting the above definition may indeed behave like a proverbial malicious troll by deliberately hiding its patents, but it may also represent a serious inventor who failed to license his inventions ex ante and years later finds them infringed.

The above definition alludes to the observation that trolls often base their business on trivial patents. Lerner (2006), in his study of litigation of patents that relate to financial products and services, obtains results that are consistent with this view. The historical examples of patent trolls in agriculture analyzed by Magliocca (2006) also support the notion of troll patents being of dubious quality, as do high-profile cases such as NTP v. Research in Motion. ${ }^{1}$

However, recent theoretical and empirical contributions suggest a more complex picture. From a game-theoretical analysis, Henkel and Reitzig (2009) derive three distinct strategies that trolls may follow. Pursuing the "injunction-based" strategy, the troll seeks a favorable settlement with the infringer under the legal threat of an injunction or some similar legal measure. Since patent invalidation proceedings usually take too long to counter such a threat, patent quality matters little for this strategy. As a result, trolls may prefer low quality patents because these are easier to obtain or harder to find for the infringer. The situation is different for the "damagesbased" and the "switching cost-based” strategy. In the former case, the troll goes after damages awarded by the court for past infringement, while in the latter case the troll exploits the high cost that the infringer would have to bear, even without time pressure, for switching to a noninfringing technology. Both of these strategies do leave enough time for invalidation proceedings, and so require legally sound patents. Empirical findings by Reitzig et al. (2009) indicate that trolls do indeed play all of these strategies.

\subsection{Sustainability of the Troll Business}

Two inefficiencies in the patent system-excessive damage awards and patentee-friendly injunctions-favor the patent troll business model (Reitzig et al., 2007), especially the first two strategies mentioned above. Infringement damages are calculated, in the majority of cases, as "reasonable royalties," which, e.g., the Directive 2004/48/EC (§13.1b) of the European

1 In March 2006, Blackberry maker Research In Motion paid an irrevocable fee of US\$ 612.5 million to NTP in an out-of-court settlement. At the time of the settlement, all five pertaining patents had already been preliminarily invalidated by the U.S. Patent and Trademark Office, a fact attesting to their low quality. See http://news.cnet.com/BlackBerry-saved/2100-1047_3-6045880.html?tag=mncol;txt (accessed 09/11/2009). 
Parliament on the enforcement of intellectual property rights defines as "the amount of royalties or fees which would have been due if the infringer had requested authorisation to use the intellectual property right in question.” However, in calculating such ex post damages, courts typically do not-although theoretically they should - take into account the hypothetical cost of replacing the infringed technology with a noninfringing alternative ex ante, i.e., before lock-in occurred (Reitzig et al., 2007). Thus, for easy-to-invent-around inventions the common calculation method leads to excessive outcomes, facilitating the damages-based troll strategy. As to the second inefficiency, generous grants of injunctions obviously favor the injunction-based troll strategy. The easier and faster it is for trolls to obtain injunctive relief, the higher their leverage in negotiations with infringers.

Legal and economics scholars have envisioned legal changes that could impede the patent troll business (Magliocca, 2006; Golden, 2007; Lemley and Shapiro, 2007) and courts and policy makers, notably in the United States, are about to address the above inefficiencies. In September 2007, the U.S. House of Representatives passed the Patent Reform Act (bill H.R. 1908), which defines "reasonable royalty" much more narrowly than then existing law. ${ }^{2}$ Since the U.S. Supreme Court's ruling in eBay Inc. v. MercExchange, L.L.C., it appears all but impossible for nonproducing entities to obtain injunctions. ${ }^{3}$ Finally, trivial patents are harder to obtain and more easily invalidated since the Supreme Court’s 2006 decision in KSR International Co. v. Teleflex, Inc. ${ }^{4}$

The above policy initiatives notwithstanding, we follow Henkel and Reitzig (2009) in their conjecture that the patent troll business model will be sustainable in the future. First of all, the troll business is favored by the patent system's lack of transparency, which makes it difficult to identify all patents that a new product might infringe upon and to determine, for a given patent, if it reads on the product or not (e.g., Bessen and Meurer, 2008). It appears unlikely, in the light of ever increasing numbers of patent applications, that this situation will improve in the near future, and so inadvertent infringement will remain hard to avoid with certainty. Regarding legal

2 See Section 5 of the bill. Note that the bill never became law. (http://www.govtrack.us/congress/bill.xpd?bill =h110-1908, accessed 09/11/2009).

3 The Supreme Court determined that an injunction should not automatically issue upon finding of patent infringement (http://www.supremecourtus.gov/opinions/05pdf/05-130.pdf, accessed 09/11/2009).

4 See http://www.supremecourtus.gov/opinions/06pdf/04-1350.pdf (accessed 09/11/2009). 
measures, not all countries have taken measures against trolls, and even in the United States some patent reform efforts have stalled (see Footnote 2). Also, trolls may learn to circumvent legal restrictions, e.g. by maintaining minor production operations in order to be considered a producing entity. Most importantly, however, the switching cost-based troll strategy is affected by neither of the legal changes sketched above. Since this strategy requires legally sound patents, we expect forward-looking trolls to acquire patents that are of high quality and thus likely to be upheld in court.

\subsection{Trolls' vs. Practicing Firms' Patent Acquisitions}

When patent trolls procure patents, be it by acquisition or by filing, they are competing for these patents with practicing firms. In fact, by the very design of the troll business model trolls are only interested in patents covering inventions that are used, or are likely to be used, by some practicing firm. In turn, if a practicing firm anticipates that trolls might procure patents on inventions it uses, it will have an interest to pre-empt the troll and secure the patent or a license to it (or, if possible, to destroy it).

Focusing on patent procurement by acquisition, the likely winner of this competition is determined by the contenders' relative abilities in two disciplines: to identify suitable patents, and to extract their value. Regarding identification, we note that procuring patents, identifying infringers, and enforcing patents against them are a patent troll's sole activities, which suggests that they should be superior to practicing firms in this discipline.

Regarding value extraction, three different uses of patents by practicing firms matter in our context (e.g., Cohen et al., 2000): a) preventing imitation or substitution of own products; b) cross-licensing with competitors in (Hall and Ziedonis, 2001; Ziedonis, 2004); and c) licensing against royalties. Except in industries in which each patented invention is used by only one practicing firm (as is often the case, e.g., in the pharmaceutical industry) and unless crosslicensing is strictly symmetrical, appropriating the full value of a patent will involve licensing against royalties. Doing so, however, will often be difficult for practicing firms, for two reasons. First, infringers may threaten to sue for infringement in turn; second, the patentee may have other business relationships with the infringer, which an infringement suit may jeopardize. Trolls, in contrast, are not vulnerable to counter-litigation for infringement nor to a termination of some other business relationship (Golden, 2006; Lemley and Shapiro, 2007; Reitzig et al., 2007), and so are in an excellent position to enforce their patents. Thus, also in extracting value from patents 
suitable for the troll business, trolls should be superior to practicing firms, and should hence be able to outplay the latter when competing for those patents.

We now discuss characteristics of patents that make them suitable for the troll business model, and from these derive three hypotheses regarding the likelihood of a patent being acquired by a troll as opposed to by a practicing firm. Our first hypothesis relates to patent scope. Since trolls rely on infringement of the patents they own, characteristics that increase the likelihood of infringement should make a patent more attractive for trolls. Such a characteristic is patent breadth. The broader the scope of a patent, the larger the number of products and processes that, ceteris paribus, will infringe upon it (Merges and Nelson, 1990). Practicing firms, on the other hand, would mainly stick to applications of the patented invention that are close to their own use of it, and hence narrow their focus on competitors and related product markets. We thus posit:

Hypothesis 1: The probability of an acquisition by a patent troll compared to an acquisition by a practicing firm increases with the scope of the patent.

The second patent characteristic patent trolls should favor is a high cost of substituting the underlying invention in products. This substitution cost increases with the difficulty of inventing around the patent, which in turn is high if the patent density and complexity of the relevant technology field is high. This means that many patents exist that have a high degree of overlap between them and with the patent under consideration, so that finding a gap for a non-patented substitutive technology is difficult. In other words, the focal patent is part of a patent thicket (Shapiro, 2001). In principle, also practicing firms could obtain royalty income by enforcing the patent against infringers, and in so doing build on high substitution costs. However, as we discussed above, patent trolls have an advantage over practicing firms in patent enforcement due to the absence of a product-based revenue model. We hence put down: ${ }^{5}$

5 In addition to increasing the cost of substitution, the fact that a patent lies in a dense and complex patent environment will likely also increase the probability of this patent being infringed. It is less clear, however, if this increased probability affects the relative attractiveness of the patent for trolls and for practicing firms in the same way as an increase in infringement probability due to scope does. This is because, from the perspective of a practicing firm, a broader scope increases the probability of infringement by products that do not directly compete with the firm's own products, while a denser and more complex patent environment should make infringement by competing products more likely. Practicing firms care about the latter type of infringement, but less about the former. In any case, these considerations do not put into question Hypothesis 2, they only make the mechanism by which density and complexity of a patent environment affect relative acquisition probabilities somewhat ambiguous. 
Hypothesis 2: The probability of an acquisition by a patent troll compared to an acquisition by a practicing firm increases with the patent density and complexity of the technological field.

Third, the legal quality of a patent, in the sense of it withstanding invalidation proceedings, is a necessary precondition for a sustainable patent troll strategy. In contrast, practicing firms in industries characterized by complex technologies (Kash and Kingston, 2001) such as electronics often use patents for cross-licensing or deterrence (instead of strict exclusion as, e.g., commonly practiced in the pharmaceutical industry). In this case, a patent's legal soundness is less critical than for a troll pursuing a sustainable strategy. Since legal soundness is closely linked to a patent's technological quality, we posit:

Hypothesis 3: The probability of an acquisition by a patent troll compared to an acquisition by a practicing firm increases with the patent's technological quality.

\section{Empirical Approach}

\subsection{Data}

To identify patent acquisitions, be they by trolls or practicing firms, we use data obtained from the European Patent Office's (EPO's) PATSTAT and INPADOC databases. While PATSTAT contains static bibliographic data on patents, the INPADOC database contains patent legal status data and in particular information on changes in ownership. While both databases are provided by the EPO, they contain data from all national patent authorities that transmit their patent bibliographic and legal status data to the EPO. We concentrate on data from the United States Patent and Trademark Office (USPTO) and the German Patent and Trademark Office (GPTO), since for these two patent authorities we are confident that both patent bibliographic and legal status data have a reliable quality in the EPOs' databases. While registering a patent acquisition at the national patent authority is not always legally required, doing so brings legal advantages for the acquirer both in the United States and in Germany. As long as the change of ownership of a patent is not registered at the patent office, a third party can acquire the patent in good faith (creating obvious disadvantages for the first acquirer). Additionally, in infringement suits plaintiffs have to prove that they are legitimized to enforce the patent. This is most easily andimportantly - most quickly done by being listed as the current patent owner in the patent register. For these reasons, the database can be assumed to comprise, for the United States and Germany, a 
large share of all patent acquisitions. We complemented the data obtained from INPADOC by data on patent characteristics from PATSTAT.

The first step in our sample construction process was to identify names of patent trolls. From extensive analyses of newspaper articles and online documents we identified the names of 80 firms operating in the United States and Germany that meet our definition of a patent troll. This sample could suffer from two types of selection biases. First, patent trolls operating recently should be easier to identify than patent trolls operating some years ago, among other things because the websites offering the richest information on troll litigation did not exist ten years ago. Second, some patent trolls could have managed to stay out of media's attention so far. However, most patent trolls try to attack as many firms as possible so that the chance that information on the troll leaks into specialized websites is high. Nonetheless, we cannot claim to provide a complete picture of all patent trolls.

Using the INPADOC database, we were able to identify 2859 patents that had undergone a change in ownership name with one of the 80 patent trolls mentioned above listed as the new owner. However, in many cases only a firm's legal form or its address had changed, or the patent had only been transferred to a subsidiary. To eliminate these false positives, we screened the data manually. In this process, we identified all sellers and made sure that they were not legally affiliated with the buyers. ${ }^{6}$ Conservatively, we also dropped all patents that had been transferred from a natural person to the acquiring firm. In these cases we were not able to ascertain if the patent had really been purchased from outside or if a founder or employee of the firm had transferred the patent to the firm. Furthermore, we learned from experts that in some cases only one patent per patent family is reassigned, to reduce cost. To avoid biases, we thus kept only one patent per patent family (the one closest to the priority filing) in our dataset if we encountered transfers of several family members. Doing so led to the deletion of 119 patents $^{7}$. We ended up with 753 patents that had been acquired by 47 distinct patent trolls (see Table 1).

For every identified patent acquired by a patent troll, we randomly selected two control patents acquired by a practicing firm in the same year within the same jurisdiction to build a

6 We did not exclude cases where the buyer acquired the "seller" along with its patents. In some cases patent trolls presumably acquired whole firms to get access to their patents. However, in most cases we do not know whether firms were acquired or only patents.

7 In only one case we found a German patent and a US patent of one family that were both transferred. In the other 118 cases we found family members applied for at the same patent authority. 
control group. Also for the patents in the control group, we manually screened each change in ownership and checked if the new patent owner is a practicing firm.

\subsection{Variables}

The dependent variable in our model is a dummy variable that captures if a patent was acquired by a patent troll or by a practicing firm. In the following we discuss our independent variables.

Patent scope. We use the number of distinct assigned four-digit IPC classes as a proxy variable for the number of possible fields of application for the technology, one dimension of patent scope often used in extant research (Lerner, 1994). Another commonly used proxy variables for patent scope is the number of claims (Lanjouw and Schankerman, 2000) or the number of claims per backward references (Harhoff et al., 2002, Lanjouw and Schankerman 1997). The problem with this indicator is that the number of claims depends on how the patent was written by the applicant (Reitzig, 2004, Lanjouw and Schankerman, 2004), while the assignment to IPC classes is carried out by the examiner and should thus be more objective.

Patent density and complexity of technology field. We measure the patent density and complexity of a technological field using the recently proposed "triple” indicator (von Graevenitz et al., 2008, 2009). ${ }^{8}$ This indicator reflects the degree of mutual blocking the patent portfolios of the biggest firms in a technological field show. Its calculation draws on the number of references classified as $\mathrm{X}$ or $\mathrm{Y}$, which means that these prior art documents have limited patentability of the invention. If two firms each own at least one patent that has block one of the other firm's patents, then these firms constitute a blocking pair. If among three firms there are three such blocking pairs, then these three firms form a triple. The triples indicator captures how many such triples exist in a given technological field. The higher the amount of triples, the more blocking dependencies between firms exist.

Patent technological quality. A patent's technological quality can be proxied by the number of forward citations it has received. The more forward citations a patent has received the higher its technological contribution to the field (Trajtenberg 1990, Harhoff and Reitzig, 2004). However, we cannot preclude that other, not technology-related effects influence the number of

$8 \quad$ Von Graevenitz et al. (2008) calculated blocking triples among patents applied for by the top 20 firms in one of 30 technology fields as defined by the OST-INPI/FhG-ISI technology nomenclature over three years. We calculated blocking triples among patents applied for by the top 100 firms in four-digit IPC class level over the last 20 years. 
forward citations (Harhoff and Reitzig, 2004). In particular citations made by the applicant may contain no information on technical quality (Reitzig, 2005). In the EPO patent examination process examiners assign citations to certain categories in order to separate technological and other citation reasons. As these assignments are stored in PATSTAT we can use them to identify technology-related citations and include this measure in a robustness check.

\subsection{Controls}

We employ a number of control variables to avoid omitted variable biases.

Proximity to basic research. Patents may also reference non-patent literature, which mostly means articles in scientific journals. The number of these references can be used as a proxy for the proximity of the patent to science (Narin et al., 1987; Meyer, 2000; Narin and Noma, 1985; Narin et al., 1997).

Age of the underlying technology. The age of the technology at time of patent acquisition is proxied by the time lapsed between filing of the priority application and acquisition of the patent. The priority date marks the time when the first application on this technology was filed at a patent authority and is thus the closest proxy to the time of invention.

Patent economic quality. A indicator of the patent's economic quality is the number of family members it has. The applicant has to pay examination and maintenance fees for every member of the patent family, and so patent family size should reflect the economic value of the patent as perceived by the applicant (Putnam, 1996; Lanjouw et al., 1996; Harhoff et al., 2003).

Crowdedness of technology field. The patent crowdedness of the patent's main technology field is measured by counting the number of patent applications in the patent's main IPC class (Harhoff and Reitzig, 2004). In our study this indicator captures whether the complexity of the patent screening process due to a more or less crowded patent environment influences patent trolls' and practicing firms' acquisition decisions.

Other Controls. We further control for the patent's number of backward references. The interpretation of this patent characteristic is not clear, though. While it is discussed to measure the extant technology in a technological field (Ziedonis, 2004) others argue that it also measures the scope of the patent (Harhoff et al., 2002). Furthermore, we control for the number of claims a patent makes. This patent characteristic is also ambiguous. Despite being used as a measure for patent's scope (Reitzig, 2005), some scholars argue that the number of claims is correlated with 
the patent's legal sustainability (Lanjouw and Schankerman, 2000, Harhoff and Reitzig, 2004). The more claims a patent has, the higher is the chance that one survives an invalidation procedure. Next, we control for effects specific to the technological fields the patents belong to, using dummy variables for all eight first-digit-level IPC classes. In addition, we use six dummy variables capturing different 5-year patent application periods (pre 1977, 1977-1981, 1982-1986, 1987-1991, 1992-1996, 1997-2001). At last, we control if the patent was already granted at time of acquisition.

\subsection{Descriptive Results}

The complete dataset contains 2259 patent acquisitions, with 753 acquisitions by patent trolls and 1506 acquisitions by practicing firms. Table 3 shows descriptive statistics. In $15 \%$ of the observations a pending application rather than a granted patent was acquired. This small share is not surprising due to the uncertainty regarding the scope and sustainability of the acquired intellectual property right. ${ }^{9}$ If a patent was not rejected in the examination process its legal sustainability increases.

In Figure 1 we show the number of patents acquired by patent trolls by main IPC sections and acquisition year. It is interesting to find that patent trolls specialize on patents in some IPC sections. Hardly any patent acquired by a patent troll is assigned to IPC sections D (Textiles and Paper), E (Fixed Constructions) and F (Mechanical Engineering, Lighting, Heating, Weapons and Blasting); most of them are related to the IPC sections G (Physics) and H (Electricity). This corresponds to the assessment of practitioners in the area of electrical engineering, stating that they are especially affected by the increase in patent trolls' patent enforcements. To give an impression which industries are preferred by patent trolls, we used the OST-INPI/FhG-ISI (OECD 1994) classification to translate IPC classes to industries. Figure 3 shows the distribution of patent trolls' acquisition by acquisition year and industry. Telecommunications and information technology are the industries in which patent trolls recently acquired most patents.

Figure 4 sheds some additional light on patent trolls’ activities on markets for technology. In our manual screening process of patent sellers, we identified if possible whether the seller is a

9 In their study on the impact of formal intellectual property rights on technology trading Gans et al. (2007) find that only $27 \%$ of technology licenses occur in the pre-allowance phase of patents. They also contribute this finding to the uncertainty of the extent of not yet granted intellectual property rights. 
practicing firm, a research institute or an intermediary like a bank or a patent broker. ${ }^{10}$ Furthermore we identified the size of the firm. Figure 4 illustrates these characteristics of the sellers of patent acquired by trolls and practicing firms, respectively. Patent trolls seem to rely to a lesser degree on large practicing firms to acquire their patents. However, we have to be cautious in interpreting these findings. For a large percentage of sellers we were not able to determine the firm size. We assume that these firms are also small and did not operate for a long time, making them harder to find in our web based search process. The share of patent acquisitions of practicing firms from small firms should thus increase since the size of more than $20 \%$ of practicing firms’ patent sources is unknown.

Comparing patents acquired by patent trolls to those acquired by practicing firms (Table 4), we find no significant differences (at the 10\% level) for family size and technology age, but (highly) significant differences in all other tested characteristics. Patent trolls clearly acquire patents that received more forward citations, are assigned to more IPC classes, lie in more complex and crowded technological fields, have more claims, and contain more non-patent literature references than patent acquired by practicing firms do.

\subsection{Model Specification}

To clearly identify those characteristics of a patent that make it relatively more attractive to a patent troll than to a practicing firm, we estimate logit models using the dummy variable “acquired by a patent troll” as the dependent variable. A logit model, estimated using maximum likelihood techniques, represents the probability of outcome 1 of the dependent variable $Y_{i}$ as a function of the covariate vector $X$ and the coefficient vector $\beta$ :

$$
\pi_{i}=\operatorname{Pr}\left(Y_{i}=1 \mid ß\right)=\left(1+\mathrm{e}^{-\mathrm{X} i ß}\right)^{-1}
$$

However, we need more sophisticated models than the standard logit estimator, for the following reason. In the step before the manual screening, we identified 2,859 patents acquired by the patent trolls we had identified, compared to 1,638,214 patent acquisitions by other entities. The need to manually filter each patent severely limited the size of the control group, which we chose to make twice as large as the group of patent troll patents. Thus, we heavily oversample

10 To do this we relied heavily on web searches since the majority of sellers was not listed in firm databases. Starting from 2259 patent transactions in our dataset, we were able to identify the business model of sellers of 2038 patents. 
patents acquired by patent trolls. In this situation - that is, if the proportion of positive outcomes in the sample does not match the proportion of positive outcomes in the population-logistic regression yields biased estimates (Prentice and Pyke, 1979; Scott and Wild, 1997). King and Zheng (2001) propose a method to correct for such oversampling of rare events. They prove that the bias in the coefficient estimates generated by oversampling rare events can be estimated using the following weighted least-squares expression:

$$
\operatorname{bias}(\hat{\beta})=\left(X^{\prime} W X\right)^{-1} X^{\top} W^{\prime} \xi
$$

where $\xi_{i}=0.5 Q_{i i}\left[\left(1+w_{1}\right) \hat{\pi}_{i}-w_{1}\right], \quad Q_{i i}$ are the diagonal elements of $Q=X\left(X^{\prime} W X\right)^{-1} X^{\prime}$, $W=\operatorname{diag}\left\{\hat{\pi}_{i}\left(1-\hat{\pi}_{i}\right) w_{i}\right\}$, and $w_{1}$ represents the fraction of ones in the sample relative to the fraction in the population. Intuitively, one regresses the independent variables $X$ on the residuals using $W$ as the weighting factor (Sorenson et al., 2006).

Tomz (1999) implemented this procedure in the relogit STATA command. We apply a logit estimator in our first model and estimate a second model using Tomz' procedure to yield unbiased coefficients for a fraction of rare events in the population of 2,859/1,638,214 ${ }^{11}$.

\section{Results}

\subsection{Findings from Main Models}

We find support for our hypothesis that patent trolls pick patents that have on average a higher probability of being infringed upon than those in the control group. The number of assigned IPC classes $^{12}$ is positive and highly significant, which confirms Hypothesis 1 . Also, the higher the patent density of a technology field, the more likely a patent in this field will be acquired by a patent troll rather than by a practicing firm, a finding that confirms Hypothesis 2. Furthermore, we find that patent trolls acquire patents that are on average of higher technological quality and thus legal sustainability than patents acquired by practicing firms (confirming Hypotheses 3). The probability of an acquisition by a patent troll increases with the (logarithmic) number of the

112,859 patents with owner name changes to a patent troll divided by 1.638.214 patents with owner name changes to firms not in our list of patent trolls.

12 The results are comparable when using the number of assigned ECLA classes. ECLA classes are more fine granular and up to date than static IPC assignments available in PATSTAT. 
patent's forward citations. ${ }^{13}$ While in line with our hypothesis, this finding is surprising. It contradicts commonly held beliefs that patent trolls concentrate on enforcing low quality patents. So, at least for those patent trolls that purposefully pick patents (rather than "discover" them on their “attic”), this belief requires revision.

Including a larger set of controls (model 3), the results remain stable. Additionally, we find that patent trolls tend to acquire patents that have on average more non-patent literature backward references. This indicator suggest that these patents have a closer proximity to basic research and are thus more difficult to substitute and have a higher likelihood to be infringed upon. However, the age of the underlying technology measured by the time lapsed between the patent's priority application and its acquisition has no impact on the relative probability of acquisition by a patent troll. Furthermore, patent trolls acquire patents that have more claims than patents acquired by practicing firms. They also acquire patents that have less backward references. Surprisingly, patent trolls tend to acquire more patents that are still in examination in relation to PEs. This finding may suggest that patent trolls trust more in their own patent quality assessment capability (since they rely less on examiners' judgement) than practicing firms do. Interestingly, the patent crowdedness of the technology field measured by the number of patent applications in the patent's main IPC has no significant influence on patent trolls' acquisitions. This finding underlines that not the crowdedness of a technological field makes it favorable for a patent troll, but the density of overlapping patent rights.

Comparing the results of the logit (Model 1) and the rare events logit (Model 2) model specifications in table 5, we see only slight differences. By and large the coefficients' signs, values and p-values are identical in both models. Since relogit corrects biased coefficients of a simple logit specification it does not provide Log-Likelihood, Pseudo-R ${ }^{2}$ and LR-Test values.

\subsection{Robustness Checks}

We complement our analysis with six robustness checks estimated with a rare events logit model specification shown in table 6 and 7 . Model 4 and model 5 have the same model specification as model 3, but use only one half of the split control data to fit the models. To be more specific, in the data construction phase we selected two practicing firms' control patents for each patent troll

13 The results are robust to the selection of specific types of forward citations. Model estimations using only the number of A-,X- respectively Y-type forward citations yielded comparable results. Also using forward citations per age of the patent yields basically the same results. 
patent. Model 4 compares the 753 patents acquired by patent trolls with a control group consisting of the first 753 practicing firms control patents (labeled as control group 1). Model 5 on the other hand compares the 753 patents acquired by patent trolls with a control group consisting of the second 753 practicing firms control patents (labeled as control group 2). The estimation results for each model shown in table 6 are nearly identical to estimation results for model 3 in table 5.

As we randomly ${ }^{14}$ selected patents for the control group and did not match control patents to patent trolls' patents by IPC section, the distribution of patents over IPC sections differs between patent troll patents and practicing firms’ patents. ${ }^{15}$ Figure 3 shows the number of patents acquired by patent trolls and practicing firms (split into control group 1 and 2) for each of the eight main IPC sections. Since patent trolls focus on IPC sections G and H, they dominate the control groups in theses two sections. In order to make double sure-in addition to using IPC class dummies in our main specifications - that different patent characteristics observed are not due to patents' different technology fields, we constructed a new control group of practicing firms' patents matched by IPC section to the patents acquired by patent trolls. For each of the 753 patent troll patents we tried to find a patent that was acquired by a practicing firm in the same year, belongs to the same patent authority and is assigned to the same first-digit main IPC section. Since manually checking each patent is a very time-consuming process we used the patents in our control groups to build the matched sample. We were able to find a match for 577 out of 753 patents acquired by patent trolls. Repeating the estimation of the specification of model 3 with this matched sample data set of 1154 patents yielded the results shown in Table 6, model 6. As practicing firms’ patents and patent troll patents were matched by their main IPC sections, we do not need to control for IPC sections in this model. The estimation results are again nearly identical to the estimation results of model 3 (and thus also to those of models 1 to $5)$.

Our last concern was that the two patent trolls which acquired most patents, IPCom with 97 patents and Rembrandt Technologies with 105 patents, are the sole cause for our estimation results in previous models. For these two patent trolls it is well known that they acquired high quality patents from leading industry players. IPCom acquired all of its patents from Bosch,

14 With the restriction that the patent was acquired in the same year and for the same jurisdiction.

15 Of course we controlled for patents' different IPC sections in the previous models. 
which had exited the market for GSM mobile telephony. Rembrandt Technology acquired the majority of its patents from a subsidiary of AT\&T. To ensure that our results are not driven by these two largest patent trolls, we estimated the model specification of model 2 on a data set without patents from IPCom and Rembrandt Technology and their corresponding control patents. The results shown as model 9 in Table 7 are again nearly identical to the results of all other models. Finally, we provide two more robustness checks in table 7 . Model 7 shows the estimation of the model specification used in model 3 for US patents only, model 8 for German patents only. The results are again stable.

\section{Discussion}

The analysis has supported our hypotheses that patent trolls acquire patents that have, relative to patents acquired by practicing firms, a higher likelihood of being infringed upon, higher substitution costs and a higher likelihood of being upheld in court and thus of being enforceable. These characteristics are clearly desirable for the patent troll business model, and our results thus show that patent trolls successfully focus on patents most suitable for their business. Yet, the finding of higher legal stability of patents acquired by trolls is surprising as it contradicts the common notion of trolls exploiting patents of dubious quality.

Our empirical analysis thus supports recent theoretical work arguing that the troll business model will be sustainable in the long run (Henkel and Reitzig, 2009). Legal countermeasures may help to limit the payoffs that trolls can achieve, and may in particular prevent gigantic settlement sums as paid by Research in Motion to NTP (see Footnote 1). However, the potentially high cost of substituting an invention once it is incorporated into a complex product will continue to provide leverage to trolls, and so their ex post approach to licensing will often be more profitable than ex ante licensing (i.e., “true” technology selling). Our results hence suggest that the troll strategy of "locking-in-to-extort” indeed needs to be added, as proposed by Henkel and Reitzig (2009), to the list of ways of exploiting the exclusion right conveyed by a patent, next to exclusion to prevent imitation and cross-licensing to coexist.

Beyond the topic of patent trolls, our results bear relevance for the theory of markets for technology more broadly. Markets for technology facilitate the transfer of technologies to firms better positioned to profit from them (Arora et al., 2001). Technology transfers thus enable firms to reap benefits of division of labor by specializing on either knowledge creation or commercialization (Lamoreaux and Sokoloff, 1999; Arora et al., 2001). As patents enable these 
markets by the specification of tradable assets in technology, scholars have emphasized the importance of the patent system for markets for technology (Gans et al., 2008; Lamoreaux and Sokoloff, 1999). In turn, transactions on markets for technology are mostly measured by observing patent licences (Gambardella et al., 2007) or patent sales (Serrano, 2008; Lamoreaux and Sokoloff 1999). However, transactions that involve patent trolls are false positives in these statistics. Neither as buyers or licensees nor as sellers or licensors of patents are trolls interested in the knowledge about the technology that a patent covers. Transactions involving trolls thus take place on the market for patents, but not on the market for technologies. This separation between an asset - knowledge — and the property right attached to it is specific to intangible assets and intellectual property rights, since only in this case the asset that is subject to a given property right may be independently recreated by parties other than the right owner. In the concrete case of patents, this separation is grounded in the fact that a firm may reinvent and practice some invention without owning or even knowing about the related patent, and in turn a patent owner may neither understand the knowledge underlying the patent nor know who else does have this knowledge and who uses it in practice.

While transactions involving patent trolls are clear-cut cases of such "patent-only" transactions, they are relatively small in number. However, it seems safe to assume that also a good share of patent transactions between practicing firms are pure patent transactions. We conjecture that many instances of cross-licensing in the fields of electronics, software, and telecommunications qualify as patent-only transactions. Using the terms "markets for technology” and "markets for patents" as synonyms thus appears to need revision.

The fact that a (possibly large) share of patent transactions do not have a corresponding transaction on the market for technology points to two inefficiencies, which constitute competing (or in fact complementary) explanations for such transactions. The first is an inefficiency in the patent system. If a firm independently came up with and practices an invention without knowing about the patent, then the prospect of being granted a patent was apparently not required for this inventor as an incentive. ${ }^{16}$ This implies that, from the point of view of incentives, patents are granted too generously (in particular, for too small inventions). The second inefficiency concerns

16 In case this firm imitated the invention on the basis of the information disclosed in the patent, it would know about the patent and would not infringe upon it inadvertently. Similarly, this firm would also know about the patent if it duplicated the invention in the course of a patent race. 
markets for technology. In a case of a patent-only transaction, reinventing the patented invention apparently had been easier than finding the patented invention and licensing it ex ante. This discussion suggests an interpretation of patent transactions that strongly differs from received wisdom. To the extent that such transactions relate to patents only, they are not indications of efficiency-enhancing technology transfers, but rather of inefficiencies in both the patent system and in markets for technology.

Our analysis has a number of management implications. In order to avoid being sued and pressed for license payments by patent trolls, practicing firms have to find ways to impede the troll business. As Henkel and Reitzig (2008) recommend, practicing firms will have to establish more advanced patent clearing and monitoring processes, so that the risk of inadvertent infringement is minimized. In the short run, practicing firms must try to hinder patent trolls to acquire patents. This is not an easy task, since-as discussed in Section 3-patent trolls have a higher valuation than practicing firms of the patents under consideration. To overcome this problem, practicing firms will have to cooperate with each other in acquiring patents before patent trolls do. Recently, some attempts in this direction were brought underway (e.g. the foundation of Allied Security Trust by Google, Cisco, Motorola, Ericsson, Sun, HP, Verizon and other companies in 2008).

An interesting avenue of further research on patent trolls is to delve deeper into the processes of how these firms procure patents. Anecdotal evidence holds that patent trolls try to actively contact small firms in particularly interesting technology fields to acquire patents. On the other hand, the advent of specialized patent auction platforms such as Oceon Tomo plays neatly into patent trolls' business model. Furthermore, we only offered a first glimpse on trolls' patent sources. It is still an open question if patent trolls buy their patents mostly from small firms unable to enforce them, or rather from large firms abandoning certain technology fields. A second interesting issue is our observation that patent trolls acquire patents of higher quality than practicing firms do. Is the commonly held belief that trolls tend to enforce simplistic patents entirely wrong, based on spectacular cases such NTP vs. RIM that hinged on patents of rather low quality? Or do patent trolls that acquire patents and patent trolls that enforce their own patents differ in this respect? Finally, and more broadly, future research that contributes to disentangling markets for patents from markets for technology should be promising. In particular, it is an open question what share of patent transactions or licenses represent technology transfers and what share merely represent transfers of rights. 


\section{References}

Arora, A., Fosfuri, A., Gambardella, A. (2001): Markets for Technology: The Economics of Innovation and Corporate Strategy. MIT Press, Cambridge MA.

Bessen, J., Meurer, M.J. (2008): Patent Failure: How Judges, Bureaucrats, and Lawyers Put Innovators at Risk. Princeton University Press, Princeton PA.

Cohen, W. M., Nelson, R. R. et al. (2000): Protecting Their Intellectual Assets: Appropriability Conditions and Why US Manufacturing Firms Patent (or Not), NBER Working Paper No. 7552, National Bureau of Economics Research, Inc, Cambridge, MA.

Gambardella, A., Giuri, P. and Luzzi, A. (2007): The market for patents in Europe. Research Policy 36: 1163-1183.

Gans, J.S., Hsu, D.H. and Stern, S. (2009): The Impact of Uncertain Intellectual Property Rights on the Market for Ideas: Evidence from Patent Grant Delays. Management Science 54(5): 982997.

Golden, J.M. (2007): “Patent Trolls” and Patent Remedies. Texas Law Review 85: 2111-2161.

Graham, S.J.H., Hall, B.H., Harhoff, D., Mowery, D.C. (2002): Post-issue patent quality control : a comparative study of US patent reexaminations and European oppositions. NBER Working Paper 8807, National Bureau of Economics Research, Inc, Cambridge, MA.

Hall, B. H. and Ziedonis, R. (2001): The Patent Paradox Revisited: An Empirical Study of Patenting in the US Semiconductor Industry, 1979-1995. Rand Journal of Economics 32(1): 101128.

Harhoff, D., Scherer, FM. Vopel, K. (2003): Citations, family size, opposition and the value of patent rights. Research Policy 32: 1343-1363.

Harhoff, D., Reitzig, M. (2004): Determinants of opposition against EPO patent grants-the case of biotechnology and pharmaceuticals. International Journal of Industrial Organization 22(4): 443-480.

Henkel, J., Reitzig, M. (2007): Patent sharks and the sustainability of value destruction strategies. Working Paper, Technische Universität München.

Jaffe, A. B., Lerner, J. (2004): Innovation and Its Discontents: How Our Broken Patent System is Endangering Innovation and Progress, and What to Do About It. Princeton, Princeton University Press.

Kash, D., Kingston, W., 2001. Patents in a world of complex technologies. Science and Public Policy 28(1), 11-22.

King, G., Zeng, L. (2001): Logistic regression in rare events data. Political Analysis 9: 137-163.

Lamoreaux, N.R. and Sokoloff, K. L. (1999): Inventive activity and the market for technology in the United States, 1840-1920. NBER Working Paper 7107, National Bureau of Economics Research, Inc, Cambridge, MA.

Lanjouw, J. and Schankerman, M. (2000): Patent Suits: Do They Distort Research Incentives? CEPR Working Paper No. 2042. 
Lanjouw, JO., Pakes, A., Putnam, J. (1998): How to count patents and value intellectual property : uses of patent renewal and applications data. Journal of Industrial Economics 46 :405432.

Lemley, M.A., Shapiro, C (2007): Patent Holdup and Royalty Stacking. Texas Law Review 85: 1991-2048.

Lerner, J. (1994): The importance of patent scope: an empirical analysis. RAND Journal of Economics 25(2): 319-333.

Lerner, J. (2006): Trolls on State Street?: The Litigation of Financial Patents, 1976-2005. Working Paper. http://www.people.hbs.edu/jlerner/Trolls.pdf (accessed 9/11/2009).

Lerner, J. (2008): The litigation of financial innovations, NBER working paper 14324, National Bureau of Economics Research, Inc, Cambridge, MA.

Levin, R. C., A. K. Klevorick, et al. (1987): Appropriating the Returns from Industrial Research and Development. Brookings Papers on Economic Activity 1987(3): 783-831.

Magliocca, G. (2006): Blackberries and Barnyards: Patent Trolls and the Perils of Innovation. Notre Dame Law Review 82: 1809.

Merges, RP. and Nelson, RR. (1990): On the complex economics of patent scope. Columbia Law Review 90: 839-916.

Meyer, M. (2000): Does science push technology? Patents citing scientific literature. Research Policy 29: 409-434.

Narin, F. and Noma, E. (1985): Is technology becoming science? Scientometrics 7 (3-6): 369381.

Narin, F., Kimberly, H. S. and Olivastro, D. (1997): The increasing linkage between U.S. technology and public science. Research Policy 26 (3): 317-330.

Narin, F., Noma, E., Perry, R. (1987) Patents as indicators of corporate technological strength. Research Policy 16 : 143-155.

OECD (1994): Using patent data as science and technology indicators. Patent manual.

Prentice, RL., Pyke, R. (1979): Logistic disease incident models and case-control studies.

Biometrica 66: 403-411.

Putnam, J. (1996): The value of international patent rights. Yale University Press, Connecticut, NJ.

Reitzig, M. (2004): Improving patent valuations for management purposes - validating new indicators by analyzing application rationales. Research Policy 33: 939-957.

Reitzig, M. (2005): On the effectiveness of novelty and inventive step as patentability requirements - structural empirical evidence using patent indicators. Copenhagen Business School Lefic Center for Law, Economics, and Financial Institutions Working Paper No. 2003-01.

Reitzig, M., Henkel, J., Heath. C. H. (2007): On sharks, trolls, and their patent prey - Unrealistic damage awards and firms' strategies of 'being infringed'. Research Policy 36: 134-154. 
Reitzig, M., Henkel, J., Schneider, F. (2009): Collateral Damage for R\&D Manufacturers: How Patent Sharks Operate in Markets for Technology. Industrial and Corporate Change. forthcoming.

Scott, AJ., Wild, CJ. (1997): Fitting logistic models under case-control or choice-based sampling. Journal of the Royal Statistical Society, B 48(2): 170-182.

Serrano, C.J. (2008): The dynamics of the transfer and renewal of patents. NBER Working Paper 13938, National Bureau of Economics Research, Inc, Cambridge, MA.

Shapiro, C. (2001): Navigating the Patent Thicket: Cross Licenses, Patent Pools and Standard Setting, in: Innovation Policy and The Economy, ed. By A. Jaffe, J. Lerner, and S. Stern, Cambridge, MA.

Sorenson, O., Rivkin, JW., Fleming, L. (2006): Complexity, networks and knowledge flow. Research Policy 35: 994-1017.

Teece, D.H. (1986): Profiting from technological innovation: Implications for integration, collaboration, licensing and public policy. Research Policy 15(6): 285-305.

Tomz, M. (1999): Relogit (Stata ado file) available at http://gking.harvard.edu/stats.shtml.

Trajtenberg, M. (1990): A penny for your quotes: patent citations and the value of innovations. RAND Journal of Economics 21: 172-187.

U.S. Federal Trade Commission (2003): To Promote Innovation: The Proper Balance of Competition and Patent Law and Policy, Washington, Government Printing Office.

Von Graevenitz, G., Wagner, S. and Harhoff, D. (2008): Incidence and Growth of Patent Thickets - The Impact of Technological Opportunities and Complexity. CEPR Discussion Paper 6900, London.

Von Graevenitz, G., Wagner, S. and Harhoff, D. (2009): How to measure patent thickets - a novel approach. Munich School of Management discussion paper 2009-9.

Ziedonis, R. (2004): Don't fence me in: fragmented markets for technology and the patent acquisition strategies of firms. Management Science 50: 804-820. 


\section{Tables and Figures}

\begin{tabular}{|c|c|c|c|c|c|}
\hline NPE & \begin{tabular}{l|} 
Acquired \\
Patents \\
US \\
\end{tabular} & \begin{tabular}{|l|} 
Acquired \\
Patents \\
DE
\end{tabular} & NPE & $\begin{array}{l}\text { Acquired } \\
\text { Patents } \\
\text { US } \\
\end{array}$ & \begin{tabular}{|l|} 
Acquired \\
Patents \\
DE \\
\end{tabular} \\
\hline Acacia Technologies & 35 & 0 & Katz Technologies & 7 & 0 \\
\hline Acceris Communications & 1 & 0 & Klausner Patent Technologies & 1 & 0 \\
\hline American Video Graphics & 26 & 0 & Mahr Leonard & 1 & 0 \\
\hline British Technology Group & 70 & 0 & Orion IP & 12 & 0 \\
\hline Catch Curve & 7 & 0 & NeoMedia Technologies & 3 & 0 \\
\hline Data Treasury & 13 & 0 & Optical Recording & 4 & 0 \\
\hline Divine Technology Ventures & 15 & 0 & Phoenix IP & 3 & 0 \\
\hline E-Fax & 1 & 0 & Pinpoint & 4 & 0 \\
\hline ESpeed & 2 & 0 & Patriot Scientific & 6 & 0 \\
\hline Firepond & 2 & 0 & PhoneTel Communications & 8 & 0 \\
\hline Forgent Networks & 1 & 0 & Polaris & 1 & 0 \\
\hline Gemstar & 12 & 0 & Rambus & 8 & 1 \\
\hline General Patent & 7 & 0 & Rates Technology & 6 & 0 \\
\hline Hoshiko & 6 & 0 & Refac Technology & 25 & 0 \\
\hline IMS Technology & 1 & 0 & Rembrandt Technologies & 105 & 0 \\
\hline INPRO Licensing & 26 & 0 & Research Corporation Technologies & 79 & 0 \\
\hline Intellect Neuroscience & 4 & 0 & SCO Group & 1 & 0 \\
\hline Intellectual Ventures & 35 & 0 & Sisvel & 13 & 0 \\
\hline Israel Bio-Engineering & 2 & 0 & Techsearch & 44 & 0 \\
\hline Intergraph & 24 & 10 & Teles & 0 & 1 \\
\hline Intertrust & 2 & 0 & TV Guide & 1 & 0 \\
\hline IP-COM & 0 & 97 & VCode Holdings & 3 & 0 \\
\hline J2 Global & 7 & 0 & Voice Capture & 1 & 0 \\
\hline JGR Acquisition & 3 & 0 & University Patents & 6 & 0 \\
\hline
\end{tabular}

Table 1 - Patent trolls in the dataset 


\begin{tabular}{|l|l|}
\hline Acquired by patent troll & $\begin{array}{l}\text { Dummy variable that indicates 1 if the patent was acquired by } \\
\text { a patent troll }\end{array}$ \\
\hline Number of assigned IPC classes & Counts the number of assigned different four-digit IPC classes. \\
\hline Number of triples & Counts the number of mutual blocking patent triples. \\
\hline Logarithmic number of forward citations & $\begin{array}{l}\text { Counts the number of forward citations the patent received. } \\
\text { The number of forward citations+1 is logarithmised to account } \\
\text { for the variable's skewness. }\end{array}$ \\
\hline Number of backward references & $\begin{array}{l}\text { Counts the number of backward references that patent makes } \\
\text { to patent literature. }\end{array}$ \\
\hline $\begin{array}{l}\text { Number of nonpatent-literature backward } \\
\text { references }\end{array}$ & $\begin{array}{l}\text { Counts the number of backward references that patent makes } \\
\text { to non-patent literature. }\end{array}$ \\
\hline Number of family members & Counts the number of family members. \\
\hline Number of claims & Counts the number of claims the patent makes. \\
\hline $\begin{array}{l}\text { Days between filing of priority application } \\
\text { and acquisition }\end{array}$ & $\begin{array}{l}\text { Counts the number of days lapsed between filing of the priority } \\
\text { application and the patent acquisition. }\end{array}$ \\
\hline Patent granted before acquisition & $\begin{array}{l}\text { Dummy variable that indicates 1 if the patent was already } \\
\text { granted at the time of acquisition }\end{array}$ \\
\hline $\begin{array}{l}\text { Number of patent applications in patents } \\
\text { main IPC / 100.000 }\end{array}$ & $\begin{array}{l}\text { Counts the number of patent applications ever filed in the } \\
\text { patents main IP class. Patent's main IPC class is the four-digit } \\
\text { level IPC class that is listed first on the patent specification. }\end{array}$ \\
\hline
\end{tabular}

Table 2 - Description of variables 


\begin{tabular}{|l|l|l|l|l|}
\hline Variable & Mean & $\begin{array}{l}\text { Standard } \\
\text { deviation }\end{array}$ & Min & Max \\
\hline & & & & \\
\hline Number of assigned IPC classes & 1.782 & 1.044 & 1 & 10 \\
\hline Number of triples & 116.373 & 253.332 & 0 & 882 \\
\hline Logarithmic number of forward citations & 1.989 & 1.328 & 0 & 6.254 \\
\hline Number of backward references & 10.981 & 13.927 & 0 & 118 \\
\hline Number of nonpatent-literature backward references & 3.159 & 9.814 & 0 & 101 \\
\hline Number of family members & 10.316 & 28.449 & 1 & 572 \\
\hline Number of claims & 16.418 & 14.733 & 1 & 165 \\
\hline Days between filing of priority application and acquisition & 3553.755 & 1848.941 & 7 & 15446 \\
\hline Patent granted before acquisition & .849 & .358 & 0 & 1 \\
\hline Number of patent applications in patents main IPC / 100.000 & 5.850 & 5.433 & 0.024 & 20.285 \\
\hline
\end{tabular}

Table 3 - Descriptive statistics

\begin{tabular}{|c|c|c|c|c|c|}
\hline & Practicin & ms' Patents & Patent Tr & Is' Patents & \\
\hline Variable & Mean & $\begin{array}{l}\text { Standard } \\
\text { deviation }\end{array}$ & Mean & $\begin{array}{l}\text { Standard } \\
\text { deviation }\end{array}$ & t-value \\
\hline Number of assigned IPC classes & 1.729 & 1.026 & 1.888 & 1.071 & 0.001 \\
\hline Number of triples & 62.409 & 183.337 & 224.300 & 328.537 & 0.000 \\
\hline $\begin{array}{l}\text { Logarithmic number of forward } \\
\text { citations }\end{array}$ & 1.776 & 1.225 & 2.417 & 1.421 & 0.000 \\
\hline Number of backward references & 11.365 & 14.305 & 10.211 & 13.114 & 0.063 \\
\hline $\begin{array}{l}\text { Number of nonpatent-literature } \\
\text { backward references }\end{array}$ & 2.569 & 9.207 & 4.337 & 10.838 & 0.000 \\
\hline Number of family members & 9.771 & 30.354 & 11.405 & 24.174 & 0.198 \\
\hline Number of claims & 15.525 & 13.095 & 18.203 & 17.429 & 0.000 \\
\hline $\begin{array}{l}\text { Days between filing of priority } \\
\text { application and acquisition }\end{array}$ & 3589.485 & 1915.433 & 3482.293 & 1707.197 & 0.194 \\
\hline Patent granted before acquisition & .859 & .349 & .831 & .375 & 0.088 \\
\hline $\begin{array}{l}\text { Number of patent applications in } \\
\text { patents main IPC / } 100.000\end{array}$ & 5.077 & 5.075 & 7.398 & 5.789 & 0.000 \\
\hline
\end{tabular}

Table 4 - Comparison of group means 


\begin{tabular}{|c|c|c|c|}
\hline & Model 1 & Model 2 & Model 3 \\
\hline & $\begin{array}{l}\text { Basic Model - } \\
\text { Only three variables }\end{array}$ & $\begin{array}{l}\text { As Model } 1- \\
\text { Only three variables }\end{array}$ & $\begin{array}{l}\text { Standard Model - } \\
\text { All variables }\end{array}$ \\
\hline Model specification & Logit & Rare Events Logit & Rare Events Logit \\
\hline Dependent variable & \multicolumn{3}{|l|}{ Acquired by Patent Troll } \\
\hline \multicolumn{4}{|l|}{ Variable } \\
\hline $\begin{array}{l}\text { Number of assigned IPC } \\
\text { sections }\end{array}$ & $\begin{array}{l}.279 * * * \\
(.517) \\
\end{array}$ & $\begin{array}{l}.276 * * * \\
(.056) \\
\end{array}$ & $\begin{array}{l}.274^{* * *} \\
(.058) \\
\end{array}$ \\
\hline Number of triples in main IPC & $\begin{array}{l}.00125^{* * *} \\
(.00022)\end{array}$ & $\begin{array}{l}.00124^{* * *} \\
(.00021)\end{array}$ & $\begin{array}{l}.00125^{* * *} \\
(.00028)\end{array}$ \\
\hline $\begin{array}{l}\text { Logarithmic number of } \\
\text { forward citation }\end{array}$ & $\begin{array}{l}.204^{* * *} \\
(.045) \\
\end{array}$ & $\begin{array}{l}.202 * * * \\
(.046)\end{array}$ & $\begin{array}{l}.291 * * * \\
(.051)\end{array}$ \\
\hline $\begin{array}{l}\text { Number of backward } \\
\text { references }\end{array}$ & & & $\begin{array}{l}-.023 * * * \\
(.005)\end{array}$ \\
\hline $\begin{array}{l}\text { Number of nonpatent- } \\
\text { literature backward references }\end{array}$ & & & $\begin{array}{l}.024 * * * \\
(.005)\end{array}$ \\
\hline Number of family members & & & $\begin{array}{l}.00124 \\
(.00214)\end{array}$ \\
\hline Number of claims & & & $\begin{array}{l}.00580^{*} \\
(.00376)\end{array}$ \\
\hline $\begin{array}{l}\text { Time between filing of } \\
\text { priority application and } \\
\text { acquisition }\end{array}$ & & & $\begin{array}{l}-.00016^{* * *} \\
(.00004)\end{array}$ \\
\hline $\begin{array}{l}\text { Patent granted before } \\
\text { acquisition }\end{array}$ & & & $\begin{array}{l}-0.821^{* * *} \\
(.178)\end{array}$ \\
\hline $\begin{array}{l}\text { Number of patent applications } \\
\text { in main IPC }\end{array}$ & & & $\begin{array}{l}0.00251 \\
(.01254) \\
\end{array}$ \\
\hline IPC section A & $\begin{array}{l}2.602 * * * \\
(.599) \\
\end{array}$ & $\begin{array}{l}2.439 * * * \\
(.590) \\
\end{array}$ & $\begin{array}{l}2.294^{* * * *} \\
(.601) \\
\end{array}$ \\
\hline IPC section $B$ & $\begin{array}{l}1.523 * * \\
(.614) \\
\end{array}$ & $\begin{array}{l}1.374 * * \\
(.604) \\
\end{array}$ & $\begin{array}{l}1.351 * * \\
(.608)\end{array}$ \\
\hline IPC section C & $\begin{array}{l}2.844 * * * \\
(.608)\end{array}$ & $\begin{array}{l}2.683 * * * \\
(.594)\end{array}$ & $\begin{array}{l}2.419 * * * \\
(.603)\end{array}$ \\
\hline IPC section $G$ & $\begin{array}{l}3.585 * * * \\
(.594) \\
\end{array}$ & $\begin{array}{l}3.414 * * * \\
(.580) \\
\end{array}$ & $\begin{array}{l}3.479 * * * \\
(.587)\end{array}$ \\
\hline IPC section $\mathrm{H}$ & $\begin{array}{l}4.196 * * * \\
(.594)\end{array}$ & $\begin{array}{l}4.022 * * * \\
(.580)\end{array}$ & $\begin{array}{l}4.023 * * * \\
(.588)\end{array}$ \\
\hline Patent application < 1977 & $\begin{array}{l}.130 \\
(.378) \\
\end{array}$ & $\begin{array}{l}0.126 \\
(.382) \\
\end{array}$ & $\begin{array}{l}1.222^{* *} \\
(.456) \\
\end{array}$ \\
\hline Patent application 1977-1981 & $\begin{array}{l}.503 \\
(.365) \\
\end{array}$ & $\begin{array}{l}0.492 \\
(.363) \\
\end{array}$ & $\begin{array}{l}1.402^{* *} \\
(.421) \\
\end{array}$ \\
\hline Patent application 1982-1986 & $\begin{array}{l}1.864 * * * \\
(.340)\end{array}$ & $\begin{array}{l}1.835^{* * *} \\
(.347)\end{array}$ & $\begin{array}{l}2.75 * * * \\
(.409) \\
\end{array}$ \\
\hline Patent application 1987-1991 & $\begin{array}{l}1.443^{* * *} \\
(.311) \\
\end{array}$ & $\begin{array}{l}1.418^{* * *} \\
(.312)\end{array}$ & $\begin{array}{l}2.252 * * * \\
(.369) \\
\end{array}$ \\
\hline Patent application 1992-1996 & $\begin{array}{l}.936 * * \\
(.298) \\
\end{array}$ & $\begin{array}{l}.914^{*} \\
(.295) \\
\end{array}$ & $\begin{array}{l}1.494 * * * \\
(.337)\end{array}$ \\
\hline Patent application 1997-2001 & $\begin{array}{l}1.149 * * * \\
(.284)\end{array}$ & $\begin{array}{l}1.126 * * * \\
(.279) \\
\end{array}$ & $\begin{array}{l}1.610^{* * *} \\
(.310)\end{array}$ \\
\hline Constant & $\begin{array}{l}-5.963 * * * \\
(1.817) \\
\end{array}$ & $\begin{array}{l}-11.417 * * * \\
(.620) \\
\end{array}$ & $\begin{array}{l}-10.467 * * * \\
(.694) \\
\end{array}$ \\
\hline Observations & $\begin{array}{l}2259 \\
\text { (753 patent trolls / } \\
1506 \text { practising firms) }\end{array}$ & $\begin{array}{l}2259 \\
\text { (753 patent trolls / } \\
1506 \text { practising firms) }\end{array}$ & $\begin{array}{l}2259 \\
\text { (753 patent trolls / } \\
1506 \text { practising firms) }\end{array}$ \\
\hline $\mathrm{LR} / \mathrm{R}^{2}$ & 670.62 / 0.2332 & & \\
\hline
\end{tabular}

Table 5 - Model estimations 


\begin{tabular}{|c|c|c|c|}
\hline & Model 4 & Model 5 & Model 6 \\
\hline & $\begin{array}{l}\text { As Model } 3- \\
\text { Troll patents and control } \\
\text { group } 1\end{array}$ & $\begin{array}{l}\text { As Model } 3- \\
\text { Troll patents and } \\
\text { control group } 2\end{array}$ & $\begin{array}{l}\text { Matched sample by IPC } \\
\text { section }\end{array}$ \\
\hline Model specification & Rare Events Logit & Rare Events Logit & Rare Events Logit \\
\hline Dependent variable & \multicolumn{3}{|l|}{ Acquired by Patent Troll } \\
\hline \multicolumn{4}{|l|}{ Variable } \\
\hline $\begin{array}{l}\text { Number of assigned IPC } \\
\text { sections }\end{array}$ & $\begin{array}{l}.318 * * * \\
(.713)\end{array}$ & $\begin{array}{l}.259 * * * \\
(.069)\end{array}$ & $\begin{array}{l}.302^{* * *} \\
(.071)\end{array}$ \\
\hline $\begin{array}{l}\text { Number of triples in main } \\
\text { IPC }\end{array}$ & $\begin{array}{l}.00104^{* * *} \\
(.00034)\end{array}$ & $\begin{array}{l}.00151^{* * *} \\
(.00037)\end{array}$ & $\begin{array}{l}.00107 * * * \\
(.00030)\end{array}$ \\
\hline $\begin{array}{l}\text { Logarithmic number of } \\
\text { forward citation }\end{array}$ & $\begin{array}{l}.307 * * * \\
(.058)\end{array}$ & $\begin{array}{l}.290 * * * \\
(.062)\end{array}$ & $\begin{array}{l}.375^{* * *} \\
(.059)\end{array}$ \\
\hline $\begin{array}{l}\text { Number of backward } \\
\text { references }\end{array}$ & $\begin{array}{l}-.022 * * * \\
(.005)\end{array}$ & $\begin{array}{l}-.025 * * * \\
(.006)\end{array}$ & $\begin{array}{l}-.027 * * * \\
(.006)\end{array}$ \\
\hline $\begin{array}{l}\text { Number of nonpatent- } \\
\text { literature backward } \\
\text { references }\end{array}$ & $\begin{array}{l}.019 * * * \\
(.007)\end{array}$ & $\begin{array}{l}.032 * * * \\
(.007)\end{array}$ & $\begin{array}{l}.029 * * \\
(.011)\end{array}$ \\
\hline Number of family members & $\begin{array}{l}-.00313 \\
(.00217)\end{array}$ & $\begin{array}{l}.00413 \\
(.00353)\end{array}$ & $\begin{array}{l}-.00135 \\
(.00283)\end{array}$ \\
\hline Number of claims & $\begin{array}{l}.00568 \\
(.00505)\end{array}$ & $\begin{array}{l}.00580 \\
(.00456)\end{array}$ & $\begin{array}{l}.012^{*} \\
(.005)\end{array}$ \\
\hline $\begin{array}{l}\text { Time between filing of } \\
\text { priority application and } \\
\text { acquisition }\end{array}$ & $\begin{array}{l}-.00021 * * * \\
(.00005)\end{array}$ & $\begin{array}{l}-.00018 * * * \\
(.00005)\end{array}$ & $\begin{array}{l}.00003 \\
(.00004)\end{array}$ \\
\hline $\begin{array}{l}\text { Patent granted before } \\
\text { acquisition }\end{array}$ & $\begin{array}{l}-.778 * * * \\
(.213)\end{array}$ & $\begin{array}{l}-.809 * * * \\
(.209)\end{array}$ & $\begin{array}{l}-1.064 * * * \\
(.240)\end{array}$ \\
\hline $\begin{array}{l}\text { Number of patent } \\
\text { applications in main IPC }\end{array}$ & $\begin{array}{l}-.00115 \\
(.01550) \\
\end{array}$ & $\begin{array}{l}.010 \\
(.015)\end{array}$ & $\begin{array}{l}.00024 \\
(.01456) \\
\end{array}$ \\
\hline IPC section A & $\begin{array}{l}2.281^{* * *} \\
(.612)\end{array}$ & $\begin{array}{l}2.19 * * * \\
(.592)\end{array}$ & \\
\hline IPC section $B$ & $\begin{array}{l}1.212^{*} \\
(.610)\end{array}$ & $\begin{array}{l}1.431^{*} \\
(.595)\end{array}$ & \\
\hline IPC section $\mathrm{C}$ & $\begin{array}{l}2.345^{* * *} \\
(.613)\end{array}$ & $\begin{array}{l}2.357 * * * \\
(.599)\end{array}$ & \\
\hline IPC section $\mathrm{G}$ & $\begin{array}{l}3.461 * * * \\
(.596)\end{array}$ & $\begin{array}{l}3.546 * * * \\
(.573)\end{array}$ & \\
\hline IPC section $\mathrm{H}$ & $\begin{array}{l}3.968 * * * \\
(.597)\end{array}$ & $\begin{array}{l}4.168 * * * \\
(.577)\end{array}$ & \\
\hline Patent application $<1977$ & $\begin{array}{l}1.134^{*} \\
(.498)\end{array}$ & $\begin{array}{l}1.565 * * \\
(.506)\end{array}$ & $\begin{array}{l}.302^{*} \\
(.541)\end{array}$ \\
\hline $\begin{array}{l}\text { Patent application 1977- } \\
1981\end{array}$ & $\begin{array}{l}1.268 * * \\
(.468)\end{array}$ & $\begin{array}{l}1.634^{* *} \\
(.472)\end{array}$ & $\begin{array}{l}.396^{*} \\
(.501)\end{array}$ \\
\hline $\begin{array}{l}\text { Patent application 1982- } \\
1986\end{array}$ & $\begin{array}{l}2.689 * * * \\
(.455)\end{array}$ & $\begin{array}{l}3.007 * * * \\
(.468)\end{array}$ & $\begin{array}{l}1.488^{* *} \\
(.445)\end{array}$ \\
\hline $\begin{array}{l}\text { Patent application 1987- } \\
1991\end{array}$ & $\begin{array}{l}2.091^{* * *} \\
(.408)\end{array}$ & $\begin{array}{l}2.556^{* * *} \\
(.412)\end{array}$ & $\begin{array}{l}1.498 * * * \\
(.412) \\
\end{array}$ \\
\hline $\begin{array}{l}\text { Patent application 1992- } \\
1996\end{array}$ & $\begin{array}{l}1.428 * * * \\
(.375)\end{array}$ & $\begin{array}{l}1.581 * * * \\
(.381)\end{array}$ & $\begin{array}{l}.942 * \\
(.381) \\
\end{array}$ \\
\hline $\begin{array}{l}\text { Patent application 1997- } \\
2001\end{array}$ & $\begin{array}{l}1.452^{* * *} \\
(.343)\end{array}$ & $\begin{array}{l}1.727 * * * \\
(.346)\end{array}$ & $\begin{array}{l}1.199 * * \\
(.361)\end{array}$ \\
\hline Constant & $\begin{array}{l}-10.653^{* * *} \\
(.669) \\
\end{array}$ & $\begin{array}{l}-11.123^{* * *} \\
(.652) \\
\end{array}$ & $\begin{array}{l}-7.899 * * * \\
(.373) \\
\end{array}$ \\
\hline Observations & $\begin{array}{l}1506 \\
\text { (753 patent trolls / } \\
753 \text { practicing firms) }\end{array}$ & $\begin{array}{l}1506 \\
\text { (753 patent trolls / } \\
753 \text { practicing firms) }\end{array}$ & $\begin{array}{l}1154 \\
\text { (577 patent trolls / } \\
577 \text { practicing firms) }\end{array}$ \\
\hline
\end{tabular}

Table 6 - Robustness checks - part 1 


\begin{tabular}{|c|c|c|c|}
\hline & Model 7 & Model 8 & Model 9 \\
\hline & $\begin{array}{l}\text { As Model } 3- \\
\text { Only US patents }\end{array}$ & $\begin{array}{l}\text { As Model } 3- \\
\text { Only DE patents }\end{array}$ & $\begin{array}{l}\text { As Model } 3- \\
\text { Without two biggest } \\
\text { patent trolls }\end{array}$ \\
\hline Model specification & Rare Events Logit & Rare Events Logit & Rare Events Logit \\
\hline Dependent variable & \multicolumn{3}{|l|}{ Acquired by Patent Troll } \\
\hline \multicolumn{4}{|l|}{ Variable } \\
\hline $\begin{array}{l}\text { Number of assigned IPC } \\
\text { sections }\end{array}$ & $\begin{array}{l}.247^{* * *} \\
(.061) \\
\end{array}$ & $\begin{array}{l}.266^{*} \\
(.194)\end{array}$ & $\begin{array}{l}.218^{* * *} \\
(.065)\end{array}$ \\
\hline $\begin{array}{l}\text { Number of triples in main } \\
\text { IPC }\end{array}$ & $\begin{array}{l}.00083^{* *} \\
(.00030)\end{array}$ & $\begin{array}{l}.00469 * * * \\
(.00115)\end{array}$ & $\begin{array}{l}.00084^{* *} \\
(.00032)\end{array}$ \\
\hline $\begin{array}{l}\text { Logarithmic number of } \\
\text { forward citation }\end{array}$ & $\begin{array}{l}.348 * * * \\
(.055)\end{array}$ & $\begin{array}{l}.576^{* *} \\
(.246) \\
\end{array}$ & $\begin{array}{l}.303 * * * \\
(.058)\end{array}$ \\
\hline $\begin{array}{l}\text { Number of backward } \\
\text { references }\end{array}$ & $\begin{array}{l}.019 * * * \\
(.005)\end{array}$ & $\begin{array}{l}-.213^{*} \\
(.085)\end{array}$ & $\begin{array}{l}.019 * * * \\
(.005)\end{array}$ \\
\hline $\begin{array}{l}\text { Number of nonpatent- } \\
\text { literature backward } \\
\text { references }\end{array}$ & $\begin{array}{l}.022 * * * \\
(.005)\end{array}$ & $\begin{array}{l}-.102 \\
(.140)\end{array}$ & $\begin{array}{l}.025^{* * * *} \\
(.006)\end{array}$ \\
\hline Number of family members & $\begin{array}{l}-.00137 \\
(.00194) \\
\end{array}$ & $\begin{array}{l}.094^{*} \\
(.042)\end{array}$ & $\begin{array}{l}-.00023 \\
(.00206)\end{array}$ \\
\hline Number of claims & $\begin{array}{l}.008^{*} \\
(.004)\end{array}$ & $\begin{array}{l}.091^{* *} \\
(.033)\end{array}$ & $\begin{array}{l}.00873^{*} \\
(.00412)\end{array}$ \\
\hline $\begin{array}{l}\text { Time between filing of } \\
\text { priority application and } \\
\text { acquisition }\end{array}$ & $\begin{array}{l}-.00019 * * * \\
(.00004)\end{array}$ & $\begin{array}{l}-.00013 \\
(.00031)\end{array}$ & $\begin{array}{l}-.00017 * * * \\
(.00005)\end{array}$ \\
\hline $\begin{array}{l}\text { Patent granted before } \\
\text { acquisition }\end{array}$ & $\begin{array}{l}-.716 * * \\
(.257)\end{array}$ & $\begin{array}{l}-.696 \\
(.442)\end{array}$ & $\begin{array}{l}-.824 * * \\
(.242)\end{array}$ \\
\hline $\begin{array}{l}\text { Number of patent } \\
\text { applications in main IPC }\end{array}$ & $\begin{array}{l}.021 \\
(.013) \\
\end{array}$ & $\begin{array}{l}-.206 * * \\
(.073) \\
\end{array}$ & $\begin{array}{l}.023^{* *} \\
(.014) \\
\end{array}$ \\
\hline IPC section $A$ & $\begin{array}{l}2.018^{* *} \\
(.607) \\
\end{array}$ & $\begin{array}{l}2.39 \\
(1.951)\end{array}$ & $\begin{array}{l}2.113^{* *} \\
(.611)\end{array}$ \\
\hline IPC section $B$ & $\begin{array}{l}1.256^{*} \\
(.614)\end{array}$ & $\begin{array}{l}.034 \\
(1.543)\end{array}$ & $\begin{array}{l}1.319 * * \\
(.619)\end{array}$ \\
\hline IPC section $\mathrm{C}$ & $\begin{array}{l}2.265^{* * *} \\
(.610) \\
\end{array}$ & & $\begin{array}{l}2.315^{* * *} \\
(.613) \\
\end{array}$ \\
\hline IPC section $G$ & $\begin{array}{l}3.212 * * * \\
(.594) \\
\end{array}$ & $\begin{array}{l}4.062 * * \\
(1.496) \\
\end{array}$ & $\begin{array}{l}3.269 * * * \\
(.599)\end{array}$ \\
\hline IPC section $\mathrm{H}$ & $\begin{array}{l}3.500 * * * \\
(.597) \\
\end{array}$ & $\begin{array}{l}5.144 * * * \\
(1.461) \\
\end{array}$ & $\begin{array}{l}3.170^{* * *} \\
(.604)\end{array}$ \\
\hline Patent application < 1977 & $\begin{array}{l}.908^{*} \\
(.499) \\
\end{array}$ & $\begin{array}{l}2.171 \\
(1.847) \\
\end{array}$ & $\begin{array}{l}.382 \\
(.501) \\
\end{array}$ \\
\hline $\begin{array}{l}\text { Patent application 1977- } \\
1981\end{array}$ & $\begin{array}{l}1.034^{*} \\
(.464) \\
\end{array}$ & $\begin{array}{l}5.600 * * \\
(2.018)\end{array}$ & $\begin{array}{l}.545 \\
(.471) \\
\end{array}$ \\
\hline $\begin{array}{l}\text { Patent application 1982- } \\
1986\end{array}$ & $\begin{array}{l}2.411 * * * \\
(.450) \\
\end{array}$ & & $\begin{array}{l}1.789 * * * \\
(.454) \\
\end{array}$ \\
\hline $\begin{array}{l}\text { Patent application 1987- } \\
1991\end{array}$ & $\begin{array}{l}1.856 * * * \\
(.418)\end{array}$ & $\begin{array}{l}1.959 \\
(.1 .529) \\
\end{array}$ & $\begin{array}{l}1.303^{* *} \\
(.421) \\
\end{array}$ \\
\hline $\begin{array}{l}\text { Patent application 1992- } \\
1996\end{array}$ & $\begin{array}{l}1.149 * * \\
(.390)\end{array}$ & $\begin{array}{l}.647 \\
(1.018)\end{array}$ & $\begin{array}{l}.465 \\
(.394)\end{array}$ \\
\hline $\begin{array}{l}\text { Patent application 1997- } \\
2001\end{array}$ & $\begin{array}{l}1.160 * * \\
(.374)\end{array}$ & $\begin{array}{l}1.820^{* *} \\
(.728) \\
\end{array}$ & $\begin{array}{l}377 \\
(.379) \\
\end{array}$ \\
\hline Constant & $\begin{array}{l}-10.467 * * * \\
(.694)\end{array}$ & $\begin{array}{l}-9.787 * * * \\
(1.841)\end{array}$ & $\begin{array}{l}-9.681^{* * * *} \\
(.691)\end{array}$ \\
\hline Observations & $\begin{array}{l}1920 \\
\text { (640 patent trolls / } \\
1280 \text { practicing firms) }\end{array}$ & $\begin{array}{l}339 \\
\text { (113 patent trolls / } \\
226 \text { practicing firms) } \\
\end{array}$ & $\begin{array}{l}1154 \\
\text { (577 patent trolls / } \\
577 \text { practicing firms) } \\
\end{array}$ \\
\hline
\end{tabular}

Table 7 - Robustness checks - part 2 


\begin{tabular}{|c|c|c|c|c|c|c|c|c|c|c|c|}
\hline & $\begin{array}{l}\text { Acquired by } \\
\text { Patent Troll }\end{array}$ & $\begin{array}{l}\text { Number of } \\
\text { assigned } \\
\text { IPC sections }\end{array}$ & $\begin{array}{l}\text { Number } \\
\text { of triples }\end{array}$ & $\begin{array}{l}\text { Logarithmic } \\
\text { number of } \\
\text { forward } \\
\text { citation }\end{array}$ & $\begin{array}{l}\text { Number of } \\
\text { backward } \\
\text { references }\end{array}$ & $\begin{array}{l}\text { Number of } \\
\text { nonpatent- } \\
\text { literature } \\
\text { backward } \\
\text { references }\end{array}$ & $\begin{array}{l}\text { Number } \\
\text { of family } \\
\text { members }\end{array}$ & $\begin{array}{l}\text { Number } \\
\text { of claims }\end{array}$ & $\begin{array}{l}\text { Time } \\
\text { between } \\
\text { filing of } \\
\text { priority } \\
\text { application } \\
\text { and } \\
\text { acquisition }\end{array}$ & $\begin{array}{l}\text { Patent } \\
\text { granted } \\
\text { before } \\
\text { acquisition }\end{array}$ & $\begin{array}{l}\text { Number } \\
\text { of patent } \\
\text { applicatio } \\
\text { ns in } \\
\text { patents } \\
\text { main IPC }\end{array}$ \\
\hline Acquired by Patent Troll & 1 & & & & & & & & & & \\
\hline Number of assigned IPC sections & 0.0720 & 1 & & & & & & & & & \\
\hline Number of triples & 0.3013 & 0.0421 & 1 & & & & & & & & \\
\hline $\begin{array}{l}\text { Logarithmic number of forward } \\
\text { citation }\end{array}$ & 0.2276 & 0.0797 & 0.1822 & 1 & & & & & & & \\
\hline Number of backward references & -0.0391 & 0.0103 & 0.0658 & 0.1983 & 1 & & & & & & \\
\hline $\begin{array}{l}\text { Number of nonpatent-literature } \\
\text { backward references }\end{array}$ & 0.0849 & 0.0750 & 0.0363 & 0.0530 & 0.3362 & 1 & & & & & \\
\hline Number of family members & 0.0271 & 0.2986 & 0.1108 & 0.1163 & 0.1935 & 0.1533 & 1 & & & & \\
\hline Number of claims & 0.0857 & 0.0468 & 0.0571 & 0.1399 & 0.2311 & 0.2211 & 0.0546 & 1 & & & \\
\hline $\begin{array}{l}\text { Time between filing of priority } \\
\text { application and acquisition }\end{array}$ & -0.0273 & 0.0005 & -0.0134 & 0.2617 & -0.0797 & -0.0721 & 0.0188 & -0.1771 & 1 & & \\
\hline Patent granted before acquisition & -0.0359 & -0.0131 & 0.0167 & 0.3480 & 0.1295 & 0.1295 & 0.0340 & 0.0050 & 0.3909 & 1 & \\
\hline $\begin{array}{l}\text { Number of patent applications in } \\
\text { patents main IPC }\end{array}$ & 0.2014 & 0.1052 & 0.5722 & 0.0764 & 0.0257 & 0.0257 & 0.1370 & 0.0450 & -0.0551 & -0.0006 & 1 \\
\hline
\end{tabular}

\section{Table 8 - Correlation matrix}




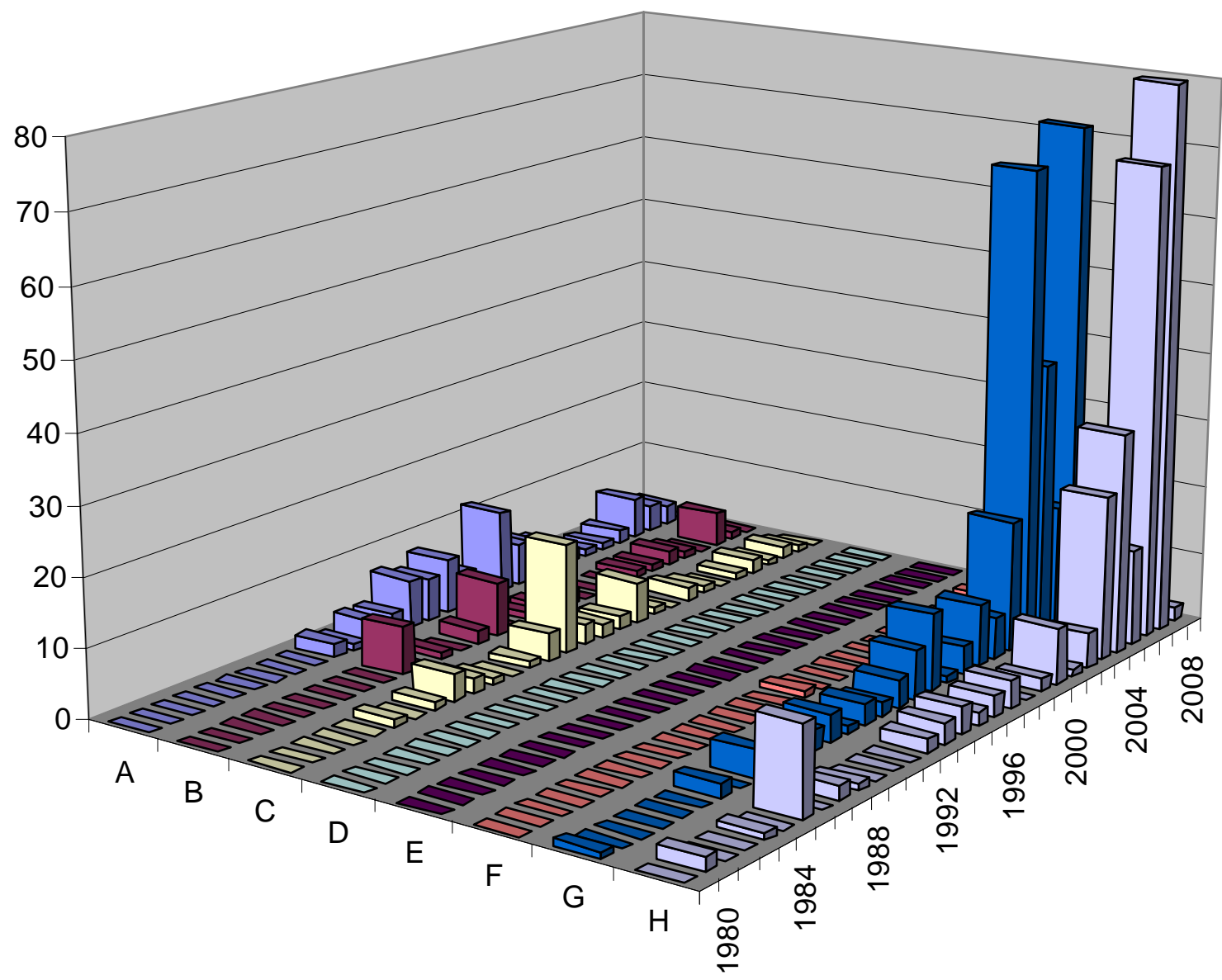

Figure 1 - Number of acquisitions by patent trolls by acquisition year and IPC class 


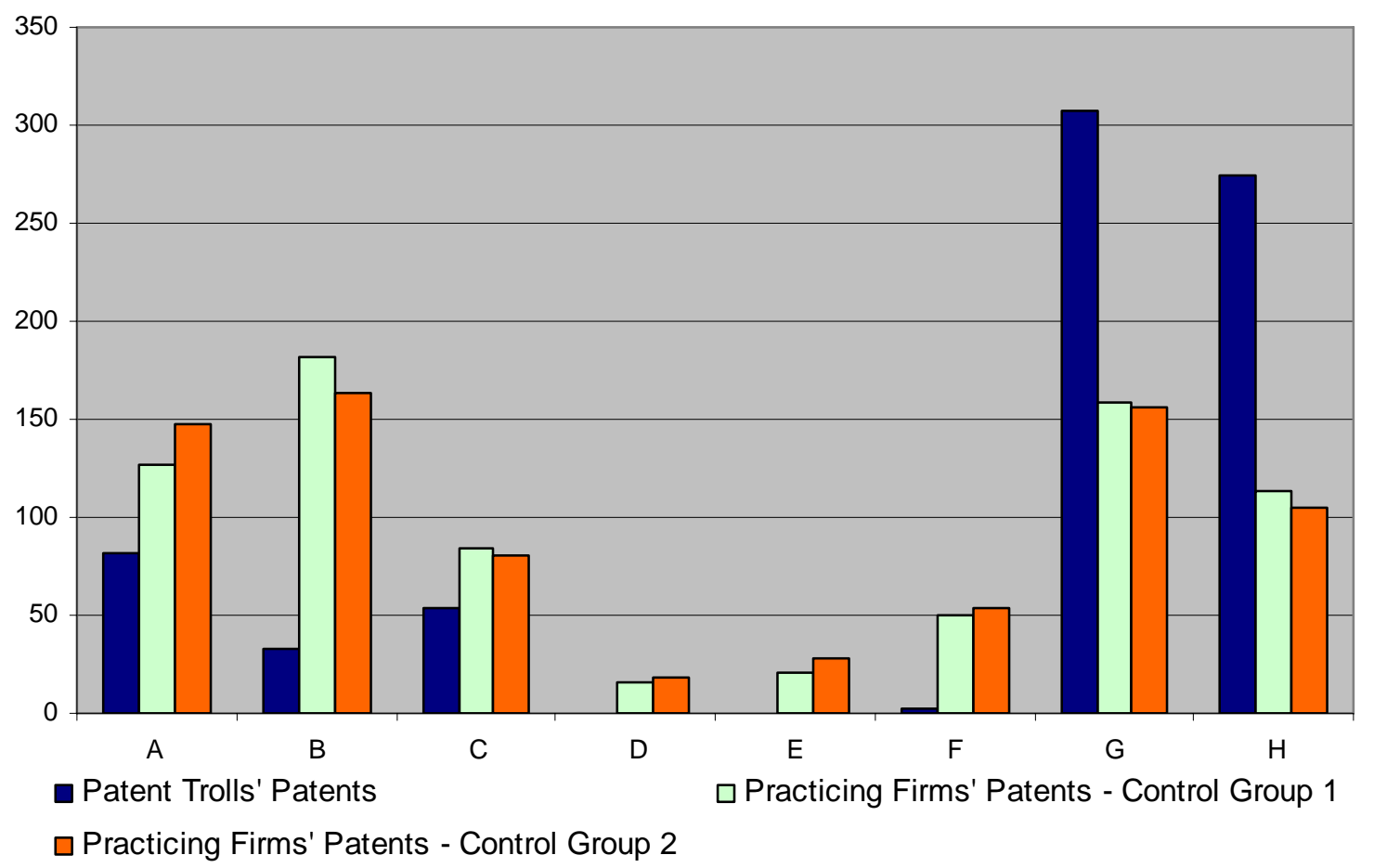

Figure 2 - Number of patents acquired by patent trolls and practicing firms by IPC class 


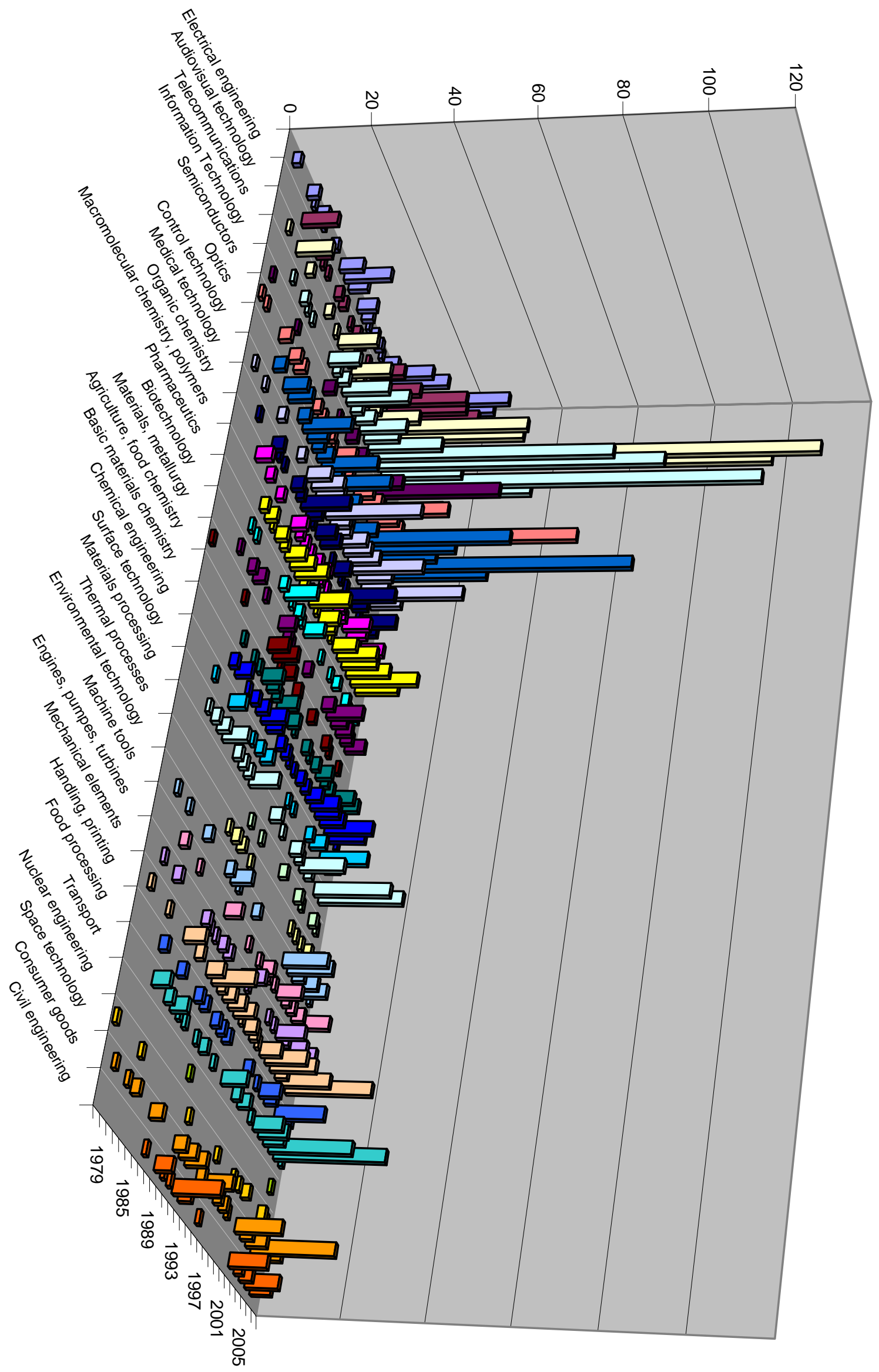

Figure 3: Number of acquisitions by patent trolls by acquisition year and technological field 


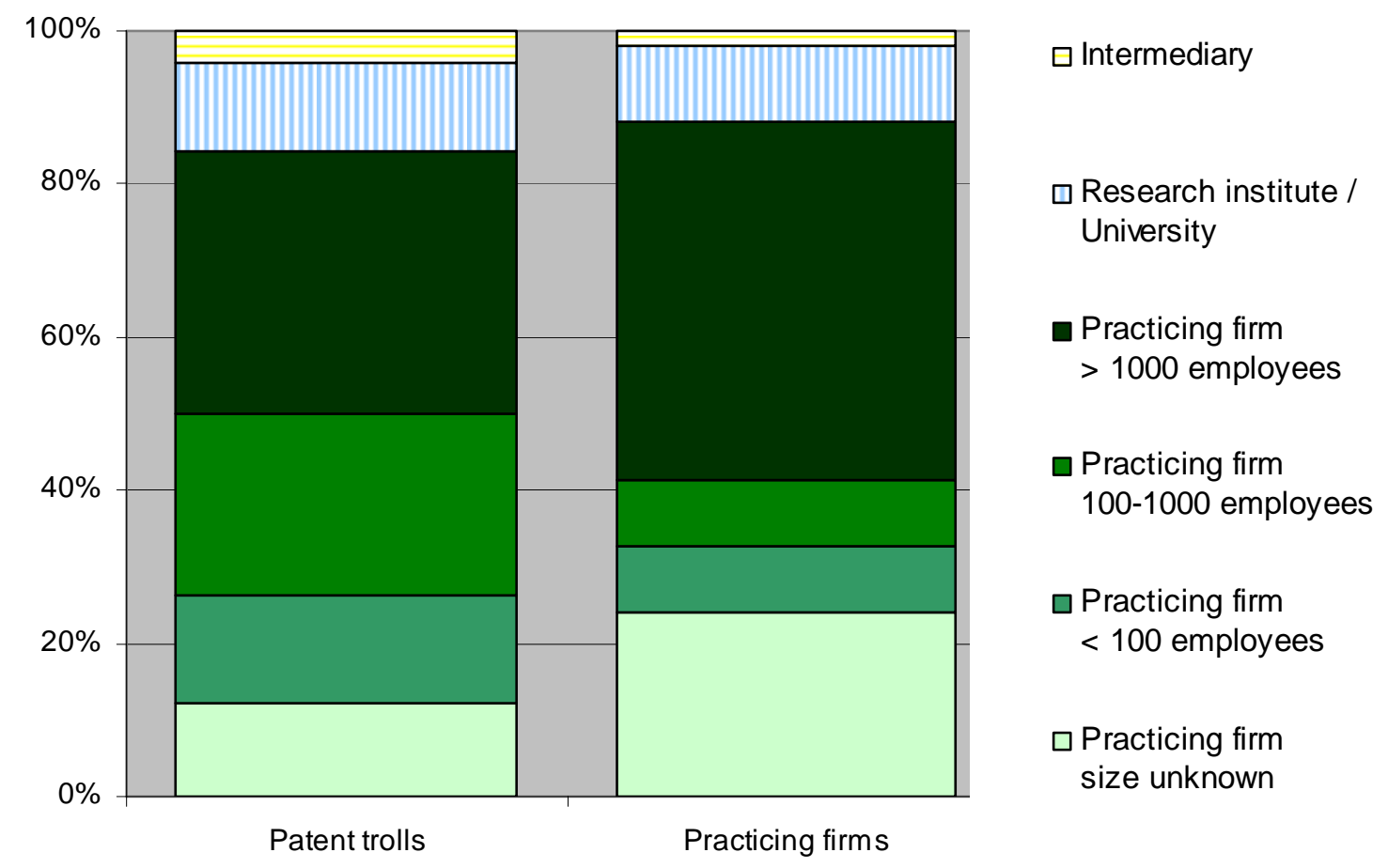

Figure: 4: Patent trolls’ sources vs. practicing firms’ patent sources 